\title{
A novel psychrotolerant member of the hymenomycetous yeasts from Antarctica: Cryptococcus watticus sp. nov.
}

Correspondence

Sharon P. Guffogg

sguffogg@pobox.une.edu.au

\author{
Sharon P. Guffogg, ${ }^{1}$ Skye Thomas-Hall, ${ }^{1}$ Paul Holloway ${ }^{2}$ \\ and Kenneth Watson ${ }^{1}$
}

${ }^{1}$ School of Biological, Biomedical and Molecular Sciences, University of New England, Armidale, NSW 2351, Australia

${ }^{2}$ School of Agricultural Science, University of Tasmania, Hobart, Tasmania 7004, Australia
Soil, snow and organic material, collected in November 1997 from the Vestvold Hills, Davis Base, Antarctica, were screened for yeasts. Two isolates, which were shown to be indistinguishable by rDNA sequencing and protein analysis by SDS-PAGE, are described in this communication as a novel species, Cryptococcus watticus sp. nov. (type culture, CBS $9496^{\top}=$ NRRL Y $-27556^{\top}$ ). Sequence analyses of the 26S rDNA D1/D2 region placed C. watticus in the hymenomycetous yeasts in a cluster with Holtermannia corniformis and Cryptococcus nyarrowii. This species has been allocated to the genus Cryptococcus on the basis of physiological and morphological characteristics.
The genus Cryptococcus is polyphyletic and is distributed throughout the Hymenomycetous yeasts, with representatives in all four clades (Tremellales, Trichosporonales, Filobasidiales and Cystofilobasidiales). Sequencing of the D1/D2 domain of the large rDNA subunit has been accomplished for all known ascomycete (Kurtzman \& Robnett, 1998) and basidiomycete (Fell et al., 2000) species. Strains that differ in this region by at least $2 \mathrm{nt}$ can be considered as potentially novel taxa (Fell et al., 2000). In a previous study by Thomas-Hall \& Watson (2002), over 500 yeasts were isolated from Antarctic soil and snow samples, from which 60 isolates were selected (on the basis of morphological characteristics) for further analysis in the current study. One-dimensional SDS-PAGE of whole-cell protein extracts was employed to identify yeast isolates with similar or visually identical protein banding patterns. This condensed the study group to 27. Phylogenetic analysis of the D1/D2 region of the large rDNA subunit sequence of two strains, $22 \mathrm{c}$ and $41 \mathrm{~b}$, showed that both strains had identical sequences and occurred in a cluster that consisted of Holtermannia corniformis, Cryptococcus nyarrowii and Cryptococcus sp. CBS 7712, CBS 7713, CBS 7743, CBS 8016, KCTC 17061, KCTC 17062 and KCTC 17063, within the Tremellales clade. These two Antarctic isolates are described in this communication as Cryptococcus watticus sp. nov.

Published online ahead of print on 1 August 2003 as DOI 10.1099/ ijs.0.02877-0.

The GenBank/EMBL/DDBJ accession number for the 26S rDNA sequence of Cryptococcus watticus is AY138478.

\section{Isolation and characterization}

Samples of soil and snow were collected in November 1997 and stored at $-10{ }^{\circ} \mathrm{C}$. Yeasts were isolated as described previously (Thomas-Hall \& Watson, 2002). Strain 41b was isolated from soil and strain $22 \mathrm{c}$ was isolated from stromatolite and shell, from samples that were taken from Watts Lake, Vestvold Hills ( $68^{\circ} 29^{\prime}$ S $78^{\circ} 25^{\prime}$ E), Davis Base, Antarctica. Cultures were maintained on yeast extract/ peptone (YEP) plates $[2 \%(\mathrm{w} / \mathrm{v})$ glucose, $0.5 \%$ bacteriological peptone, $0.5 \%$ yeast extract, $0.3 \% \mathrm{KH}_{2} \mathrm{PO}_{4}, 0.3 \%$ $\left(\mathrm{NH}_{4}\right)_{2} \mathrm{SO}_{4}, 1.5 \%$ agar] and in aqueous stocks at $6{ }^{\circ} \mathrm{C}$, with long-term storage in $15 \%$ glycerol at $-80^{\circ} \mathrm{C}$. Isolates were characterized by the standard methods described by Yarrow (1998).

\section{DNA sequence analysis}

An AquaPure Genomic DNA Isolation kit from Bio-Rad was employed to extract DNA from the yeast isolates. PCR products were obtained by utilizing the Qiagen HotStart PCR kit [ $2 \mu \mathrm{l}$ purified DNA, $0 \cdot 5 \mu \mathrm{l}$ forward primer ( $5^{\prime}$-TCCGTGTTTCATGAACCTGCGG-3'), $0 \cdot 5 \mu \mathrm{l}$ reverse primer (5'-TCCTCCGCTTATTGATATGC-3'), $21 \cdot 5 \mu \mathrm{l}$ MilliQ water, $2 \cdot 5 \mu \mathrm{l}$ Q-solution, $25 \mu \mathrm{l}$ HotStart Mastermix], followed by thermal cycling using the following conditions: $95^{\circ} \mathrm{C}$ for $15 \mathrm{~min}$, followed by 30 cycles of $94^{\circ} \mathrm{C}$ for $1 \mathrm{~min}$, $52^{\circ} \mathrm{C}$ for $1 \mathrm{~min}$ and $72{ }^{\circ} \mathrm{C}$ for $1 \mathrm{~min}$, with a final $10 \mathrm{~min}$ at $72^{\circ} \mathrm{C}$. PCR products were purified with the Prep-a-geneclean system (Bio-Rad). A Beckman CEQ2000 Dye Terminator Quick Start kit was used for the sequencing reaction of the D1/D2 domain in a total volume of $20 \mu \mathrm{l}$ [purified PCR product, $2 \mu \mathrm{l}$ primer (forward primer MLF 


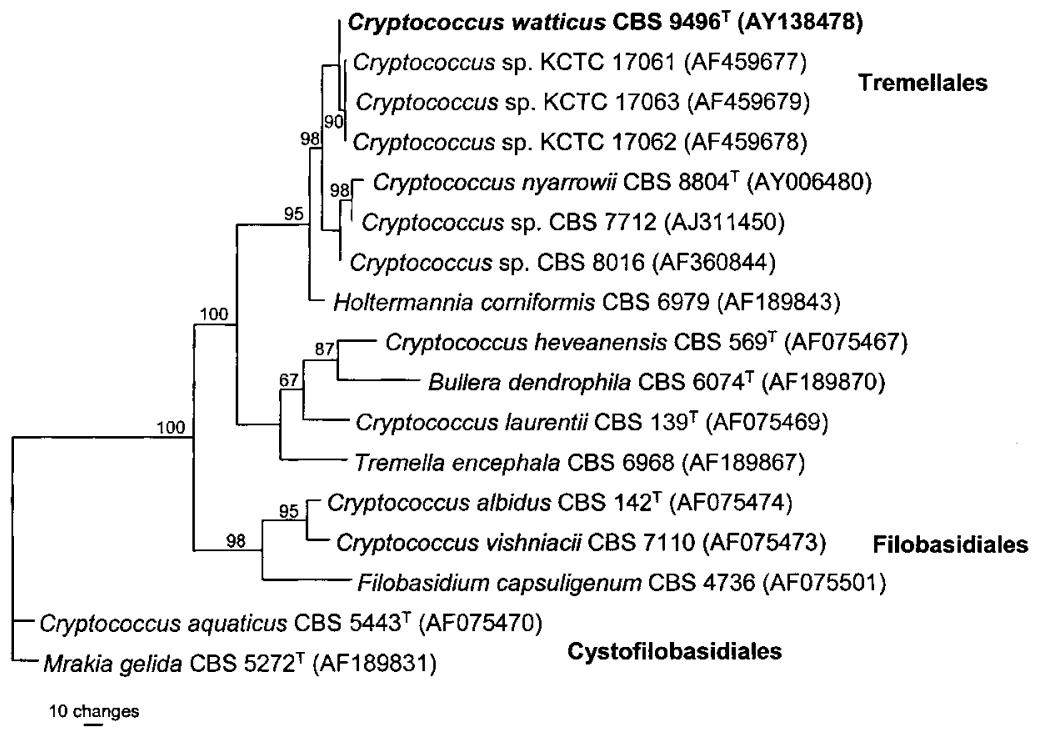

Fig. 1. Phylogenetic tree showing placement of $C$. watticus among related basidiomycetous yeasts, derived from maximum-parsimony analysis of the $26 \mathrm{~S}$ rDNA D1/D2 domain. Bootstrap replications from 100 full heuristic replications using the neighbour-joining method are displayed. Cryptococcus aquaticus and Mrakia gelida, which represent the Cystofilobasidiales, are the designated outgroup species in this analysis. Labelled clades have representative species only.

5'-GCATATCAAGCGGAGGAAAAG-3', reverse primer MLR 5'-GGTCCGTGTTTCAAGACGG-3'), 4 l Beckman CEQ DTCS Quickstart mix, $14 \mu \mathrm{l}$ MilliQ water] and was placed in the thermal cycler for 30 cycles of $96^{\circ} \mathrm{C}$ for $20 \mathrm{~s}$, $50{ }^{\circ} \mathrm{C}$ for $20 \mathrm{~s}$ and $60{ }^{\circ} \mathrm{C}$ for $4 \mathrm{~min}$. Sequences were obtained with a Beckman CEQ2000 automatic sequencer and aligned visually with BioEdit. Phylogenetic relationships were assessed with MegAlign (DNAStar). Phylogenetic analyses employed the maximum-parsimony program of PAUP 4.0 (Sinauer Associates) with heuristic searches and neighbourjoining analysis. Bootstrap values were determined by using PAUP; values of $<50 \%$ were not included in tree figures.

\section{Fatty acid and protein pattern analyses}

Cells were grown to stationary phase in $100 \mathrm{ml}$ YEP broth and fatty acid composition and whole-cell protein patterns were determined as described previously (Thomas-Hall \& Watson, 2002).

Sixty isolates from the original 500 yeasts that were isolated in a previous study (Thomas-Hall \& Watson, 2002) were chosen for further analysis on the basis of morphological characteristics. One-dimensional SDS-PAGE of whole-cell proteins was employed initially to characterize relatedness among unknown isolates by comparing protein banding patterns. Isolates with visually identical or similar protein banding patterns were grouped together. Two isolates, 22c and $41 \mathrm{~b}$, were shown to have protein banding patterns that were indistinguishable from each other, but differed significantly from those of $C$. nyarrowii and $H$. corniformis (results not shown). Phylogenetic analyses revealed that the two isolates have identical sequences and have $2 \mathrm{nt}$ difference from the Korean strains KCTC 17061, KCTC 17062 and KCTC 17063, 15 nt difference from H. corniformis and $16 \mathrm{nt}$ difference from C. nyarrowii, resulting in their placement in the Tremellales clade with other isolates from Antarctica (C. nyarrowii and Cryptococcus strains CBS
7712, CBS 7713 and CBS 7743) (Fig. 1). Fatty acid analysis of strain $41 \mathrm{~b}$ revealed oleic acid $\left(\mathrm{C}_{18: 1}\right)$ to be the predominant fatty acid present $(61 \%)$, together with the polyunsaturated fatty acids $\mathrm{C}_{18: 2}(5 \%)$ and $\mathrm{C}_{18: 3}(3 \%)$, whereas strain $22 \mathrm{c}$ showed significant amounts of $\mathrm{C}_{18: 1}(28 \%)$ and the polyunsaturated fatty acids $\mathrm{C}_{18: 2}(31 \%)$ and $\mathrm{C}_{18: 3}$ (11\%). These fatty acid compositions confirmed previous studies that have shown that psychrophilic Antarctic yeasts, such as species of the genera Candida, Leucosporidium and Mrakia, have a high unsaturated fatty acid content (Watson, 1987). The new yeast isolates were placed in the genus Cryptococcus, as no sexual state was observed under a variety of conditions. Vegetative reproduction is by multilateral budding (Fig. 2), D-glucuronate and inositol are assimilated and urease and Diazonium blue $\mathrm{B}$ reactions are positive (Fell \& Statzell-Tallman, 1998; Kurtzman \& Fell, 1998).

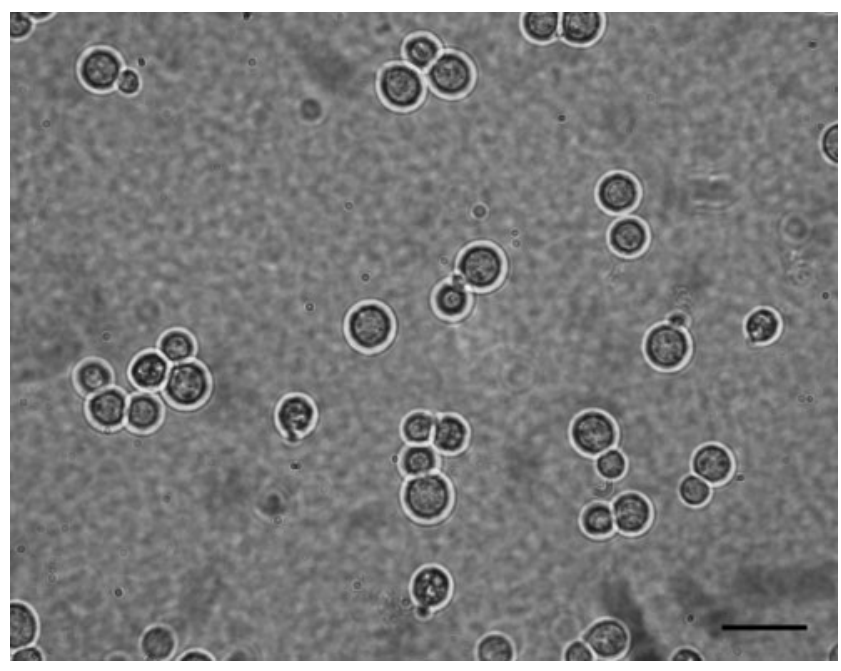

Fig. 2. Cryptococcus watticus after 3 days at $15^{\circ} \mathrm{C}$ in YEP broth, showing budding cells. Bar, $10 \mu \mathrm{m}$. 


\section{Description of Cryptococcus watticus Guffogg, Thomas-Hall, Holloway \& Watson sp. nov.}

Cryptococcus watticus (wat'ti.cus. N.L. adj. watticus referring to Watts Lake, Antarctica, from where the isolates originated).

After 3 days growth in YEP broth at $15{ }^{\circ} \mathrm{C}$, cells are ovoidal and occur singly or in pairs. Budding is polar. Aerobic growth results in pink, convex, circular colonies with an entire margin. Colonies are viscous in consistency. No sexual state is observed from mixed or pure cultures plated for 3-6 months at 6 or $15^{\circ} \mathrm{C}$ on YEP agar, cornmeal agar, malt agar or nitrogen base agar. Growth on yeast nitrogen base agar or cornmeal agar is slower than on YEP or malt agar. Assimilation of carbon compounds is as follows: positive reactions are observed for glucose, galactose, sucrose, trehalose, lactose, melibiose, raffinose, inulin, D-xylose, D-ribose, L-rhamnose, $\mathrm{N}$-acetyl-D-glucosamine, D-mannitol, methyl $\alpha$-D-glucoside, salicin, succinate, citrate, inositol and D-glucuronate; negative or weak reactions are observed for D-arabinose, D-glucosamine, glycerol, erythritol, ribitol, D-glucitol, hexadecane, L-sorbose, maltose, cellobiose, melezitose, L-arabinose, methanol, ethanol, galactitol, D-gluconate and DL-lactate. Assimilation of soluble starch is weak. Assimilation of nitrate is positive. Growth in vitamin-free medium, 50\% $(\mathrm{w} / \mathrm{w})$ glucose/yeast extract agar and $10 \% \mathrm{NaCl} / 5 \%$ glucose is negative. Growth is positive in both biotin- and thiaminfree media. Gelatin liquefaction and urease reaction are positive. Diazonium blue B reaction is positive. Starch formation is negative. Growth at $25^{\circ} \mathrm{C}$ is weak; no growth occurs at $30^{\circ} \mathrm{C}$.

The type strain is $41 \mathrm{~b}^{\mathrm{T}}\left(=\mathrm{CBS} 9496^{\mathrm{T}}=\mathrm{NRRL} \mathrm{Y}-27556^{\mathrm{T}}\right)$. These strains were isolated from soil (41b) and stromatolite and shell (22c), Watts Lake, Vestvold Hills, Davis Base $\left(68^{\circ} 29^{\prime} \mathrm{S} 78^{\circ} 25^{\prime} \mathrm{E}\right)$, Antarctica.

\section{Latin diagnosis of Cryptococcus watticus Guffogg, Thomas-Hall, Holloway et Watson sp. nov.}

In YEP liquido post dies 3 ad $15^{\circ} \mathrm{C}$, cellulae ovoidae sunt, singulae vel binae. Flosculi sunt polares. Incrementum cum aere effecit luteas, convexas, rotundas colonias margine toto. Coloniae sunt consistentiae crassae. Status sexualis non apparet culturis in agaro YEP, farinae Zea mays, malti, vel nitrogeneo 3-6 menses. Ex agaro nitrogeneo vel farinae Zea mays est minus quam ex agaro YEP vel malti. Assimilat sic: glucosum, galactosum, sucrosum, trehalosum, lactosum, melibiosum, raffiniosum, inulinum, D-xylosum, D-ribosum, L-rhamnosum, N-acetyl-D-glucosaminum, D-mannitolum, methyl- $\alpha$-D-glucosidum, salicinum, succinatum, citratum, inositolum et $\mathrm{D}$-glucuronatum; non respondent $\mathrm{D}$-arabinosum, D-glucosaminum, glycerolum, erythritolum, ribitolum, Dglucitolum, hexadecanum, L-sorbosum, maltosum, cellobiosum, melezitosum, L-arabinosum, methanolum, ethanolum, galactitolum, D-gluconatum, DL-lactatum. Exigue respondet amylum solubile. Respondet nitratum. Incrementum sine vitamina, ex $50 \%(\mathrm{w} / \mathrm{w}) \mathrm{GY}$ agaro, $10 \% \mathrm{NaCl}, 5 \%$ glucosum non respondet. Incrementum respondet sine biotino et sine thiamin. Liquatio gelatinis et ureum respondent. Amylum non creatur. Incrementum ad $25{ }^{\circ} \mathrm{C}$ exigue est, ad $30{ }^{\circ} \mathrm{C}$ non est.

In collectione zymotica Centraalbureau voor Schimmelcultures, Utrecht, Nederlandia, CBS $9496^{\mathrm{T}}$ (=NRRL $\left.\mathrm{Y}-27556^{\mathrm{T}}\right)$ est Cryptococcus watticus. Haec est isolata ex terra, testa Watts Lake, Vestvold Hills, Davis Base $\left(68^{\circ} 29^{\prime} \mathrm{S}\right.$ $\left.78^{\circ} 25^{\prime} \mathrm{E}\right)$, Antarctica.

\section{Acknowledgements}

Funding for this research was supported by the Australian Research Council, University of New England internal research grants (K. W.) and a University of New England postgraduate scholarship (S. G.). Thanks are due to David Nichols and Kevin Sanderson, University of Tasmania, Hobart, for access to Antarctic soil samples and use of their laboratory, Charles Tesoriero, University of New England, for the Latin translation and Jack Fell for insightful comments on the manuscript.

\section{References}

Fell, J. W. \& Statzell-Tallman, A. (1998). Cryptococcus Vuillemin. In The Yeasts, a Taxonomic Study, 4th edn, pp. 742-767. Edited by C. P. Kurtzman \& J. W. Fell. Amsterdam: Elsevier.

Fell, J. W., Boekhout, T., Fonseca, A., Scorzetti, G. \& StatzellTallman, A. (2000). Biodiversity and systematics of basidiomycetous yeasts as determined by large-subunit rDNA D1/D2 domain sequence analysis. Int J Syst Evol Microbiol 50, 1351-1371.

Kurtzman, C. P. \& Fell, J. W. (1998). Summary of species characteristics. In The Yeasts, a Taxonomic Study, 4th edn, pp. 915-947. Edited by C. P. Kurtzman \& J. W. Fell. Amsterdam: Elsevier.

Kurtzman, C. P. \& Robnett, C. J. (1998). Identification and phylogeny of ascomycetous yeasts from analysis of nuclear large subunit (26S) ribosomal DNA partial sequences. Antonie van Leeuwenhoek 73, 331-371.

Thomas-Hall, S. \& Watson, K. (2002). Cryptococcus nyarrowii sp. nov., a basidiomycetous yeast from Antarctica. Int J Syst Evol Microbiol 52, 1033-1038.

Watson, K. (1987). Temperature relations. In The Yeasts, 2nd edn, vol. 2, pp. 42-71. Edited by A. H. Rose \& J. S. Harrison. London: Academic Press.

Yarrow, D. (1998). Methods for the isolation, maintenance, classification and identification of yeasts. In The Yeasts, a Taxonomic Study, 4th edn, pp. 77-101. Edited by C. P. Kurtzman \& J. W. Fell. Amsterdam: Elsevier. 